\title{
A methodology to estimate equity of canal water and groundwater use at different spatial and temporal scales: a geo-informatics approach
}

\author{
Usman Khalid Awan' (D) Arif Anwar ${ }^{2} \cdot$ Waqas Ahmad $^{2} \cdot$ Mohsin Hafeez $^{3}$
}

Received: 28 January 2015/ Accepted: 29 September 2015

(C) Springer-Verlag Berlin Heidelberg 2016

\begin{abstract}
Indus basin irrigation system (IBIS) is one of the largest contiguous irrigation systems of the world. The surface canal water supplies are far less than the crop water demands which lead farmers to use groundwater to cope surface water scarcity. Although many studies in the IBIS are conducted to analyze the equitable distribution of canal water, there is hardly any study which comprehensively analyze the equitable use of canal water and groundwater at different spatial and temporal scales. One of the main reasons is lack of reliable information on the volume of groundwater abstraction. The objective of the current study is to develop an approach for estimating the equity of canal water and groundwater use at different spatial (canal command, distributaries, head, middle and tail end reaches) and temporal (daily, monthly and seasonal) scales of Hakra canal command area of IBIS. Results show that canal water and groundwater use to meet actual evapotranspiration is 34 and $42 \%$, respectively, which makes groundwater as an integral part of the large canal irrigation schemes of IBIS. The canal water and groundwater use varies significantly during the cropping colander. The maximum groundwater use is during May $(51 \mathrm{~mm})$ whereas the maximum canal water use is during August ( $24 \mathrm{~mm}$ ). Farmers located at the head end reaches of Hakra canal use $42 \%$ groundwater of total groundwater use whereas farmers located at the
\end{abstract}

Usman Khalid Awan

u.k.awan@cgiar.org

1 International Center for Agricultural Research in the Dry Areas (ICARDA), Cairo, Egypt

2 International Water Management Institute, IWMI Office, Lahore, Pakistan

3 School of Environmental Science, Charles Sturt University, Albury, Australia middle and tail end reaches use only 35 and $23 \%$, respectively. The canal water use at the head, middle and tail end reaches is 40,34 and $26 \%$, respectively. These results show that the farmers located at the head of Hakra canal command area use more canal water and groundwater as compared to those located at the middle and tail end reaches. This methodology can provide guidelines to water managers in the region for equitable use of both canal water and groundwater.

Keywords Canal command area $\cdot$ SEBAL $\cdot$ Water scarcity · Groundwater abstraction · Indus basin

\section{Introduction}

The Indus basin irrigation system of Pakistan (IBIS) "by design" delivers scarce water quantities at all hierarchies. Historical evidence shows that the widespread irrigation system was never designed on the irrigation principle of adequacy and reliability and was part of the British colonial irrigation era policy. Rather the objective of the colonial policy was to extend the agriculture to all areas of Indus basin where agriculture could flourish. This would keep the rural population engaged in agriculture, avoid conflicts, protection against drought and famine and hence secure the colonial rule (Jurriens et al. 1996). Following on from the green revolution, rice and sugarcane have emerged as important cash crops (Jurriens et al. 1996; Brewer et al. 1999) and farmers have started looking for more than growing only wheat and vegetables. Due to the introduction of high yielding seeds, commercialization of agriculture and the increase in cropping intensities, the colonial era water allowances have now became inadequate. Farmers were found to respond to this scarcity by engaging 
in water thefts, tampering the outlets, exchanges in warabandi times, and most importantly supplementing canal irrigation with tubewell irrigation. Moreover groundwater assisted poor farmers in the IBIS not only to improve their livelihoods, but also to reduce their vulnerability against surface water shortages and droughts. Today, groundwater not only provides more than $50 \%$ of the total crop water requirements in the Indus basin (Shah 2007) but has become an integral part of the irrigated agricultural environment in the Indus basin. Unfortunately, the excessive use of this precious resource with continued mismanagement has led to unsustainability. Today, a major concern is how to maintain sustainable long-term yields from these aquifers (Todd and Mays 2005). It is now a well-recognized fact that groundwater is a finite and vulnerable resource within the irrigated areas of the IBIS and it must be used in an efficiently manner for present and future generations.

However, the lack of groundwater management institutions, poor water intuitions, undefined groundwater management policy and no priority to regulate groundwater abstraction has brought into question the sustainability of groundwater use in the IBIS. A significant concern is that there is scant data and reliable information available on groundwater abstraction at a high spatial and temporal resolution. An estimated figure of $50 \%$ groundwater abstraction for Indus basin is being used by different researchers. However, groundwater abstraction varies across the Indus basin depending upon groundwater salinity, groundwater levels and availability of canal water. In this paper, we used a geo-informatics approach (combining GIS and remote sensing techniques) to estimate the groundwater abstraction at a range of spatial scales, i.e., canal command area, at distributary level and at head, middle and tail end reaches. The benefits of geo-informatics techniques are the availability of spatial and temporal data and these techniques also have become a very handy tool in exploring, evaluating, and managing vital groundwater resources in data sparse regions (Chowdhury et al. 2003). Moreover, remote sensing has made it possible to develop a strategic plans for surface and groundwater resources at a high spatial and temporal resolution (e.g., Bastiaanssen et al. 1998; Jha et al. 2006; Meijerink et al. 2007; Muthuwatta et al. 2010; Awan et al. 2011; George et al. 2002) and at watershed level (Vieceli et al. 2014). The estimation of groundwater abstraction by geo-informatics approaches is much more accurate than conventional direct and indirect methods (Ahmad et al. 2005). The methodology used in this paper has already been successfully implemented in different parts of the world (e.g., Ahmad et al. 2005; Castaño et al. 2010; Le Page et al. 2012). In this methodology, satellite-derived actual evapotranspiration (Bastiaanssen et al. 1998) is used as a main input to estimate net groundwater use. Efficiencies at farm and network level are then incorporated to estimate total groundwater abstraction. In current study we are introducing a new framework of canal water and groundwater equity. This framework incorporates the spatial and temporal variation of gross and net canal water irrigation and gross and net groundwater irrigation at detailed spatial and temporal scales by satellite remote sensing.

\section{Materials and methods}

\section{Study area}

The Hakra canal command area is situated in the southeast of Punjab province of Pakistan and has semi-arid climate (Fig. 1). The long-term annual average reference evapotranspiration $\left(\mathrm{ET}_{0}\right)$ and rainfall from the official climatic data for the last 20 years in the study region are 1678 and $250 \mathrm{~mm}$, respectively (Fig. 2). The resulting difference between crop water demand and rainfall is fulfilled by canal water and groundwater resources. The total irrigated area of Hakra canal command area is 203,140 ha. There are 17 distributaries which convey water from Hakra canal to the farmer's field via a network of water courses and farm channels. The area irrigated by each distributary is managed by a unit of public-private partnership. Typically, farmers elect representatives of this unit for tenure of 3 years. The mandate of this unit is to achieve water equity, improve cost recovery, and encourage farmer participation for management of their irrigation water. These management units are known as farmer organizations leading by a president who again is elected by farmers through an election procedure. There are 17 Farmers Organizations (FO's) established in Hakra canal command area (Fig. 1) and are responsible for equity of canal water distribution in their respective areas.

\section{A framework for canal water and groundwater equity}

A frame work was established to capture the equity of canal water and groundwater for Hakra the canal command area, all the distributaries of Hakra canal command area and head, middle and tail end reaches of the Hakra canal command area. Moreover, gross and net canal water and groundwater irrigation was estimated at monthly, seasonal and yearly time steps (Fig. 3).

\section{Canal water}

Gross canal water irrigation (ICW $\left.W_{\text {gross }}\right)$ The main source of surface irrigation to Hakra canal command area is canal 


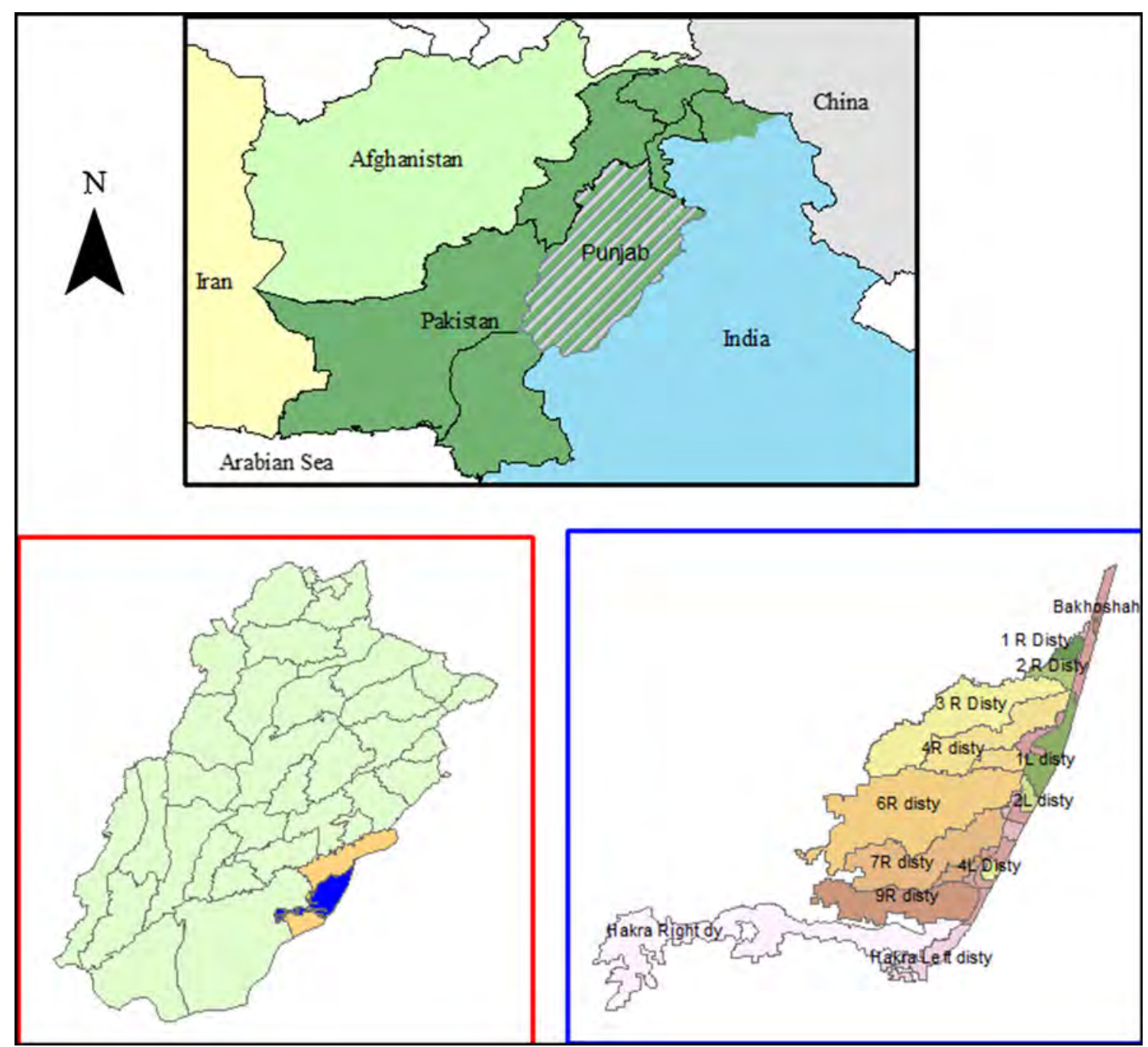

Fig. 1 Location of distributaries in Hakra canal command area of Punjab province of Pakistan

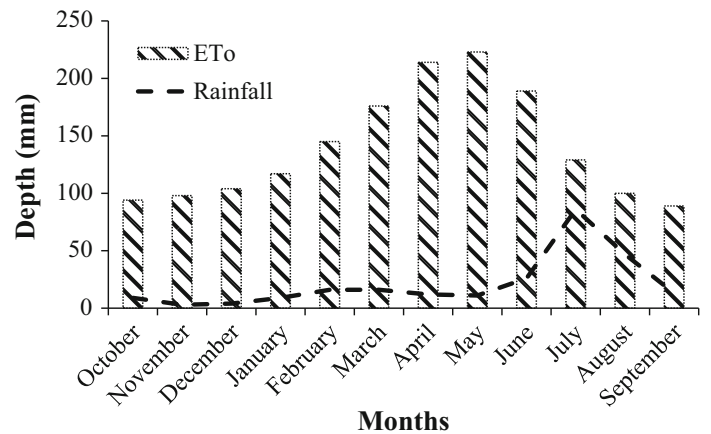

Fig. 2 Monthly reference evapotranspiration $\left(\mathrm{ET}_{0}\right)$ and rainfall data for the Hakra canal command area

water irrigation from the Hakra branch canal. Water from Hakra branch canal is diverted to distributaries by regulating structures. The discharge measurement and regulation remains the responsibility of the Punjab Irrigation
Department (PID). PID uses stream-gauging technique to measure the discharge in these distributaries. In this method used by PID, the depth (stage) of water in distributary is used to determine the discharge. To measure the water depth at head, staff-gauges are installed in at the head of these distributaries. For any stage, the corresponding value of discharge is determined from a stagedischarge rating curve. Typically, discharge is measured twice a day. The Programme Monitoring and Implementation Unit (PMIU) of the PID is responsible for measuring discharges and maintaining an online database of this data. The discharges at the head of each distributary were collected from PMIU and then aggregated on a daily, monthly, and then seasonal basis.

Figure 4 shows the off-take point of each distributary and the area irrigated by that distributary.

Table 1 lists the 17 distributaries of the Hakra Branch canal. There are also direct watercourses taking water 


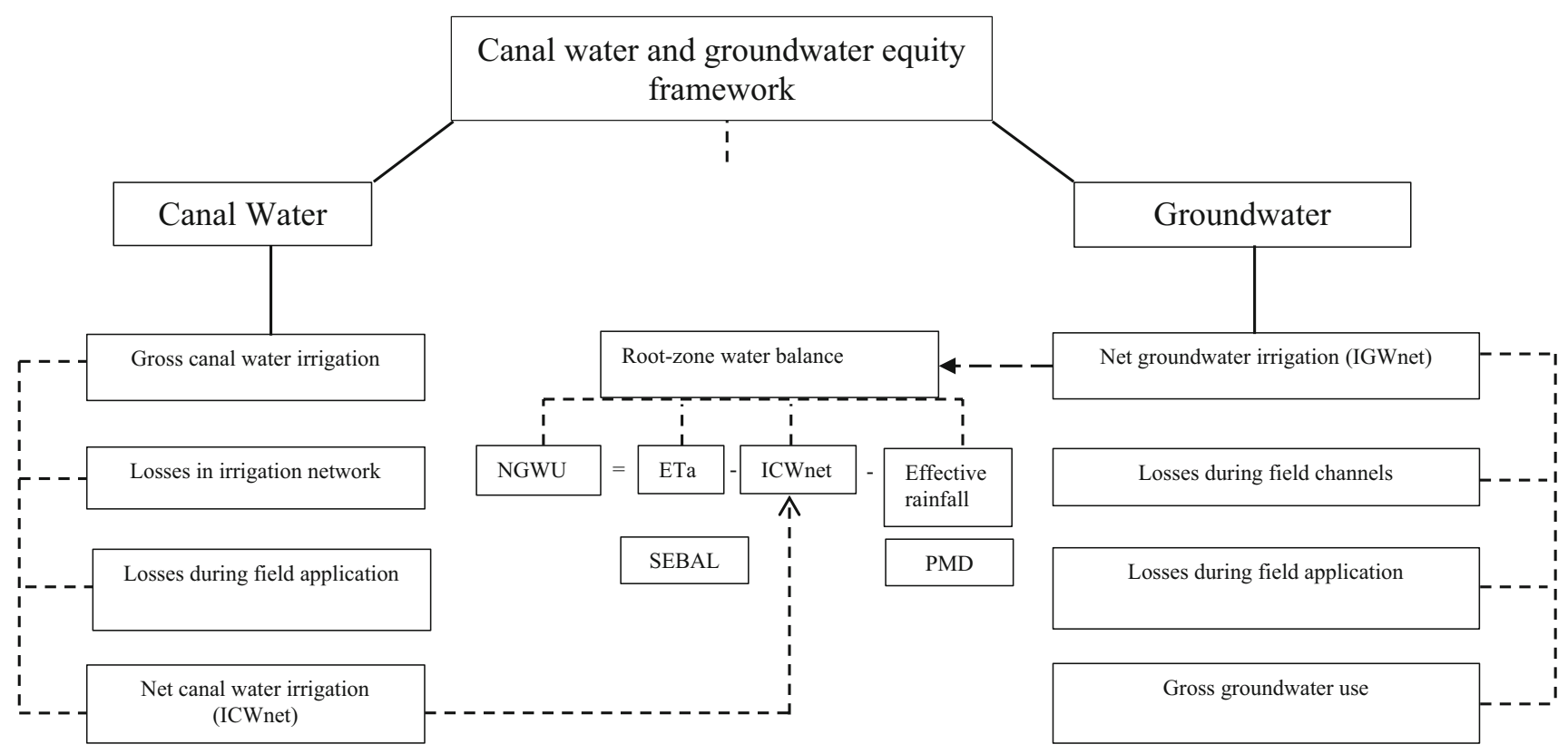

$\mathrm{ETa}=$ Actual Evapotranspiration, SEBAL $=$ Surface Energy Balance Algorithm for Land, PMD = Pakistan

metrological department

\begin{tabular}{|c|c|c|c|c|c|c|}
\hline \multicolumn{7}{|c|}{$\begin{array}{c}\text { Spatial and temporal scale of canal water and groundwater } \\
\text { use }\end{array}$} \\
\hline \multicolumn{7}{|c|}{$\begin{array}{l}\text { This approach describes the comparison (\% or } \mathrm{mm} \text { ) of canal water and groundwater use at } \\
\text { following spatial and temporal scales }\end{array}$} \\
\hline \multirow{5}{*}{ 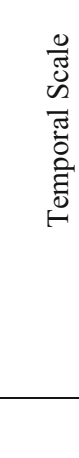 } & Monthly & $\checkmark$ & $\checkmark$ & $\checkmark$ & $\checkmark$ & $\checkmark$ \\
\hline & Seasonal & $\checkmark$ & $\checkmark$ & $\checkmark$ & $\checkmark$ & $\checkmark$ \\
\hline & Annual & $\checkmark$ & $\checkmark$ & $\checkmark$ & $\checkmark$ & $\checkmark$ \\
\hline & & Head & Middle & Tail & Disty & $\mathrm{CCA}$ \\
\hline & \multicolumn{6}{|c|}{ Spatial Scale } \\
\hline
\end{tabular}

Fig. 3 A framework for canal water and groundwater equity

directly from the Hakra branch canal. Based upon the reduced distance (RD) concept, three spatial scales along the Hakra canal are developed e.g., head, middle and tail reaches of the Hakra canal (Table 1). In Pakistan RD is used to measure the length of the canal from head of the canal to downstream and $1 \mathrm{RD}$ is equal to 1000 feet. The irrigation depth for canal water, groundwater and actual evapotranspiration is integrated between these spatial units.
Net canal water irrigation (ICWnet) Irrigation water available at the root-zone or net canal water irrigation is calculated using the irrigation efficiency concept i.e., water available at head of distributary multiplied by the irrigation efficiency (field and irrigation network efficiency). In order to incorporate irrigation network and field application losses, results from a study conducted by Hussain et al. (2011) were used. According to this study, irrigation 


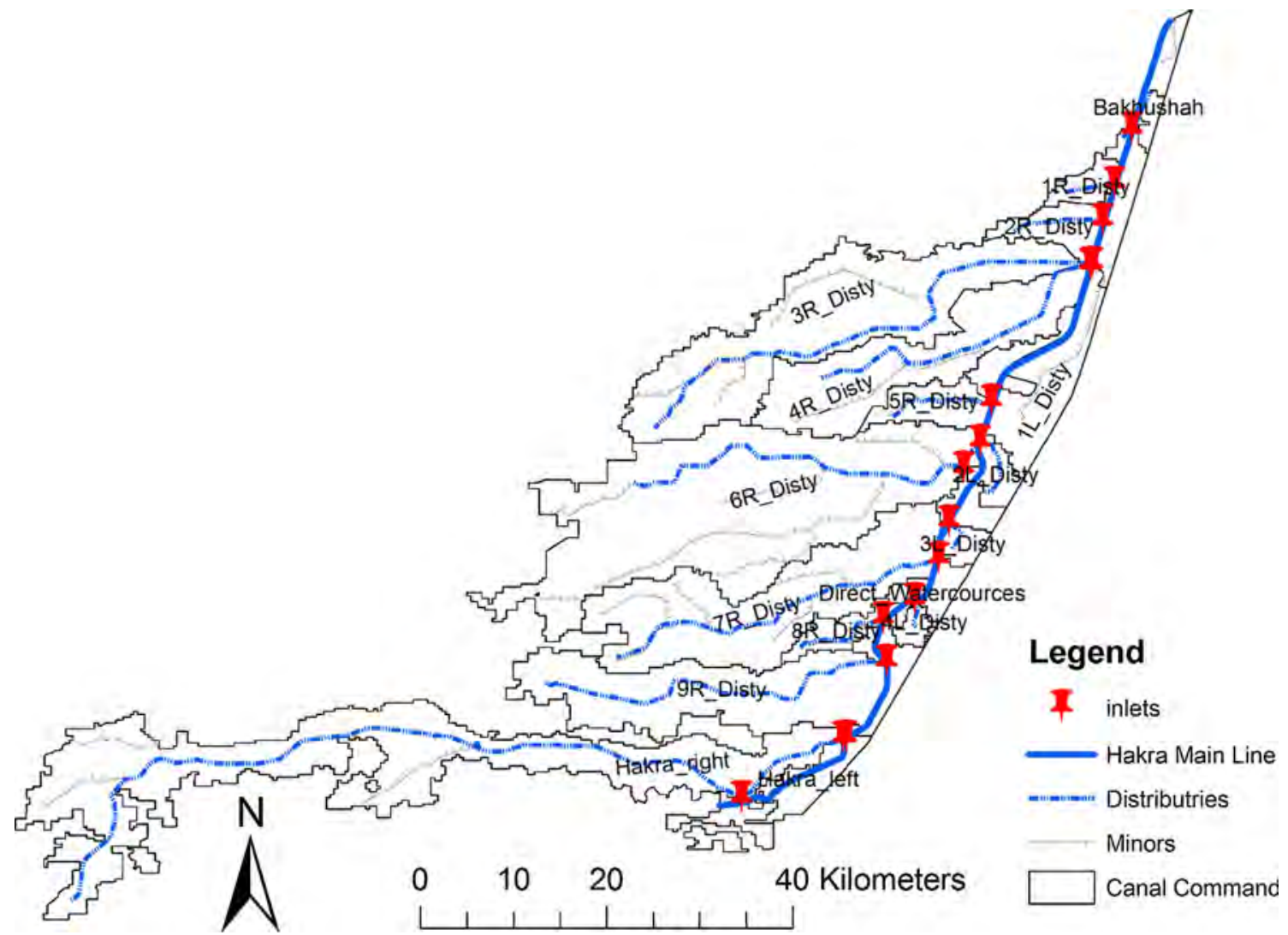

Fig. 4 Location of inlet points of different distributaries in Hakra canal command area

Table 1 Location different distributaries in Hakra canal command area

\begin{tabular}{llrr}
\hline Distributary & Parent channel & GCA (ha) & CCA (ha) \\
\hline Head & & & \\
Mubarik (1L) Disty & Hakra branch & 7518 & 6920 \\
Sundar (1R) Disty & Hakra branch & 2062 & 2010 \\
Mianwala (2L) Disty & Hakra branch & 1964 & 1770 \\
Dunga Bunga (2R) Disty & Hakra branch & 2149 & 2148 \\
Malkir (3L) Disty & Hakra branch & 722 & 703 \\
Khatan (3R) Disty & Hakra branch & 45,945 & 29,455 \\
Middle & & & \\
Kamrani (4L) Disty & Hakra branch & 855 & 682 \\
Haroonabad (4R) Disty & Hakra branch & 28,249 & 17,593 \\
Bhagsen (5R) Disty & Hakra branch & 4271 & 3715 \\
Mamun (6R) Disty & Hakra branch & 49,821 & 41,222 \\
Khichiwala (7R) Disty & Hakra branch & 26,770 & 21,804 \\
Josar (8R) Disty & Hakra branch & 2912 & 2574 \\
Tail & & & \\
Sardrewala (9R) Disty & Hakra branch & 20,206 & 19,917 \\
Hakra Left Disty & Hakra branch & 2457 & 2419 \\
Hakra Right Disty & Hakra branch & 45,485 & 42,911 \\
Flood Channel Disty & Hakra branch & 9141 & 6687 \\
\hline
\end{tabular}

network efficiency and field application efficiency for the study region is 48 and $75 \%$, respectively. This results in an irrigation efficiency of $36 \%$ for the study region.

\section{Groundwater}

Net groundwater irrigation $\left(I G W_{\text {net }}\right)$ Geo-informatic techniques are used to estimate net groundwater use in the Hakra canal command area. According to this approach, net groundwater use can be estimated by establishing the water balance in the unsaturated zone (root-zone).

$\mathrm{ET}_{\mathrm{a}}-\mathrm{ICW}_{\text {net }}-P=\mathrm{IGW}_{\text {net }}$

where $\mathrm{Et}_{\mathrm{a}}=$ actual evapotranspiration; $\quad \mathrm{ICW}_{\text {net }}=$ net canal water irrigation; $P=$ rainfall; and $\mathrm{IGW}_{\text {net }}=$ net groundwater irrigation. Secondary data is used to estimate net canal water irrigation at distributary level whereas the surface energy balance algorithm for land (SEBAL) model is used to estimate actual evapotranspiration. A detailed methodology to estimate these parameters is described in the following sections.

Actual evapotranspiration by surface energy balance algorithm for land (SEBAL) SEBAL is a satellite-based remote sensing surface energy balance algorithm for land. 
The detailed formulation of this algorithm is presented by Bastiaanssen et al. (1998). Further, this model is validated under diverse ago-climatic conditions by Bastiaanssen et al. (1998). Researchers report that without calibration the model showed an accuracy of $95 \%$ which can also be an instrumental error. This model has been consistently used in several water balance studies across the globe (e.g., Awan et al. 2011; Hellegers et al. 2009; Karatas et al. 2009; Conrad et al. 2007; Hafeez et al. 2007).

The theory of this model is based on a research study conducted in Pakistan by Bastiaanssen et al. (1998). The actual evapotranspiration is residual product of surface energy budget which is given as below:

$R_{\mathrm{n}}=G_{0}+H+\lambda E$

where $R_{\mathrm{n}}=$ net radiation $\left(\mathrm{W} \mathrm{m}{ }^{-2}\right) ; G_{0}=$ soil heat flux $\left(\mathrm{W} \mathrm{m}{ }^{-2}\right) ; H=$ sensible heat flux $\left(\mathrm{W} \mathrm{m}^{-2}\right)$; and $\lambda E=$ latent heat flux $\left(\mathrm{W} \mathrm{m}^{-2}\right)$.

Bastiaanssen et al. (2002) introduced the evaporative fraction concept according to which Eq. (2) can be expressed as a latent heat flux by considering evaporative fraction and net available energy $\left(R_{\mathrm{n}}-G_{0}\right)$ :

$\lambda E=\Delta\left(R_{\mathrm{n}}-G_{0}\right)$

where $\Delta$ is evaporative fraction and can be described as:

$\Delta=\frac{\lambda E}{R_{\mathrm{n}}-G_{0}}=\frac{\lambda E}{\lambda E+H}$

The net available energy $\left(R_{\mathrm{n}}-G_{0}\right)$ can be estimated from instantaneous timescale to daily or to monthly timescale. For timescales of 1 day, soil heat flux can be ignored and net available energy reduces to net radiation $\left(R_{\mathrm{n}}\right)$ by which actual evapotranspiration on daily basis can be calculated as:

$\mathrm{ET}_{24}=\frac{86400 \times 10^{3}}{\lambda \times \rho_{\mathrm{w}}} \times \Delta \times R_{\mathrm{n} 24}$

where $R_{\mathrm{n} 24}=24 \mathrm{~h}$ averaged net radiation; $\lambda=$ latent heat of vaporization; and $\rho_{\mathrm{w}}=$ density of water.

Satellite data Land cover, land surface temperature, land surface albedo are essential variables in estimation of actual evapotranspiration (Bandara 2006). Recent development in remote sensing makes it possible to estimate these parameters for different satellite sensors (Hafeez et al. 2007). In current study, we used MODIS (Moderateresolution Imaging Spectroradiometer) data for its optimal spectral bands, high temporal resolution (8 days) and data products required for SEBAL. Table 2 shows MODIS standard products which are used in current study and can be downloaded free from the MODIS data distribution website (https://lpdaac.usgs.gov/get_data/data_pool). A total of 69 images were downloaded for land surface temperature (MOD11A2), land surface reflectance (MOD09Q1) and normalized daily vegetation index (NDVI) (MOD13A2). These products are the main input required by SEBAL model to estimate other variables of energy budget and eventually actual evapotranspiration.

Climatic data Climatic data needed for this study were collated from Punjab Metrological Department (PMD). The data includes rainfall, wind speed, mean and maximum air temperature, relative humidity, and solar radiation. The long-term annual average reference evapotranspiration $\left(\mathrm{ET}_{0}\right)$ for the study area was calculated by the Hargreaves method (Hargreaves and Samani 1985) is $1678 \mathrm{~mm}$ whereas crop specific evapotranspiration is $1313 \mathrm{~mm}$.

Gross groundwater irrigation (IGW $\left.W_{\text {gross }}\right)$ The gross water irrigation is the total amount of groundwater abstracted by the farmers for irrigating their specific crops. It is calculated by dividing the net groundwater use with irrigation efficiency. Irrigation efficiency is losses in the field channels while conveying water from the tubewells to the farmer fields and losses during field applications. For current study, we used the conveyance losses of $16 \%$ described by Hussain et al. (2011).

\section{Results and discussion}

\section{Actual evapotranspiration}

The annual actual evapotranspiration $\left(\mathrm{ET}_{\mathrm{a}}\right)$ in the Hakra canal command area varies significantly within all the distributaries with a maximum and minimum values of 939 and $460 \mathrm{~mm}$, respectively, with an average of $676 \mathrm{~mm}$ $\left( \pm 124 \mathrm{~mm}\right.$ ) (Fig. 5). The maximum $\mathrm{ET}_{\mathrm{a}}$ is for $1 \mathrm{R}$ distributary which is located at the head of the Hakra canal whereas the minimum value is for Hakra left which is located at the tail of the Hakra canal. The monthly values of $\mathrm{ET}_{\mathrm{a}}$ not only varies significantly between different distributaries but also within the months. The maximum monthly average $\mathrm{ET}_{\mathrm{a}}$ values are during the month of July
Table 2 MODIS data used for SEBAL algorithm

\begin{tabular}{llrl}
\hline Product name & Dataset & Spatial resolution $(\mathrm{m})$ & Sensor \\
\hline MOD09Q1 & Land surface reflectance (band 1 and band 2) & 250 & TERRA \\
MOD11A2 & Land surface temperature and emissivity & 1000 & TERRA \\
MOD13A2 & NDVI & 1000 & TERRA \\
\hline
\end{tabular}


Fig. 5 Actual

evapotranspiration on monthly (a) and annual (b) basis in different distributaries of Hakra canal command area

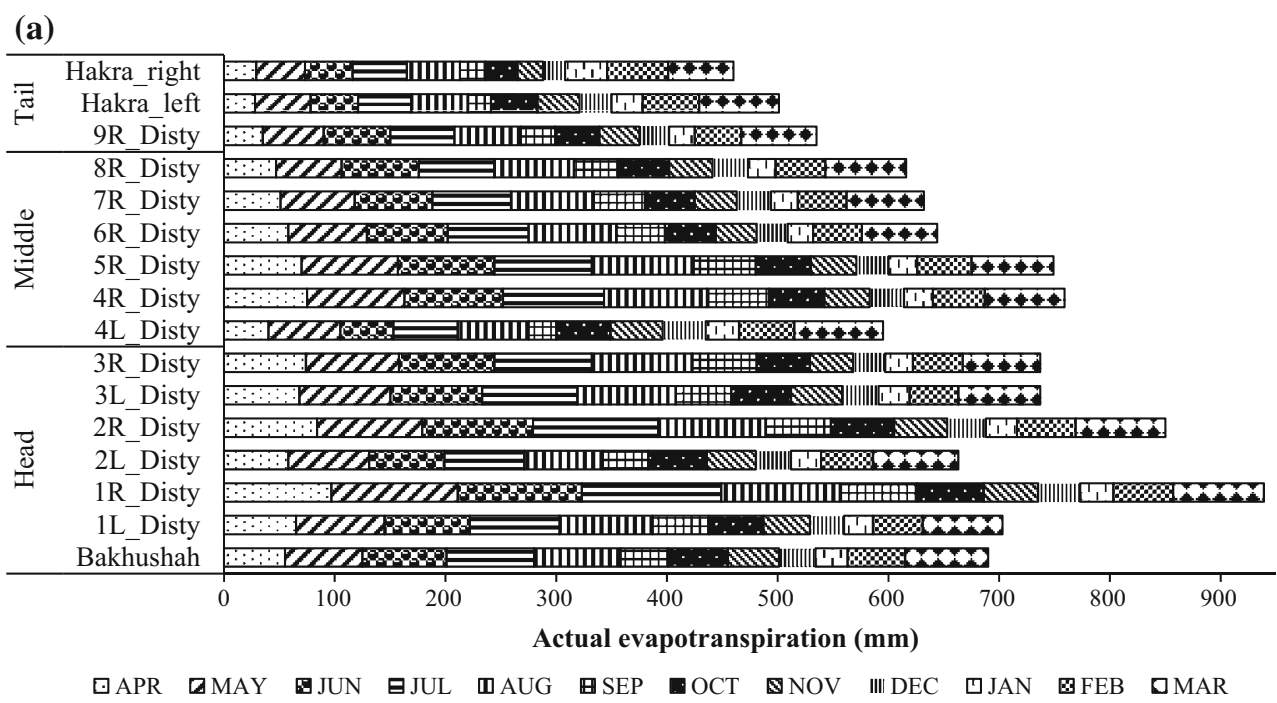

(b)

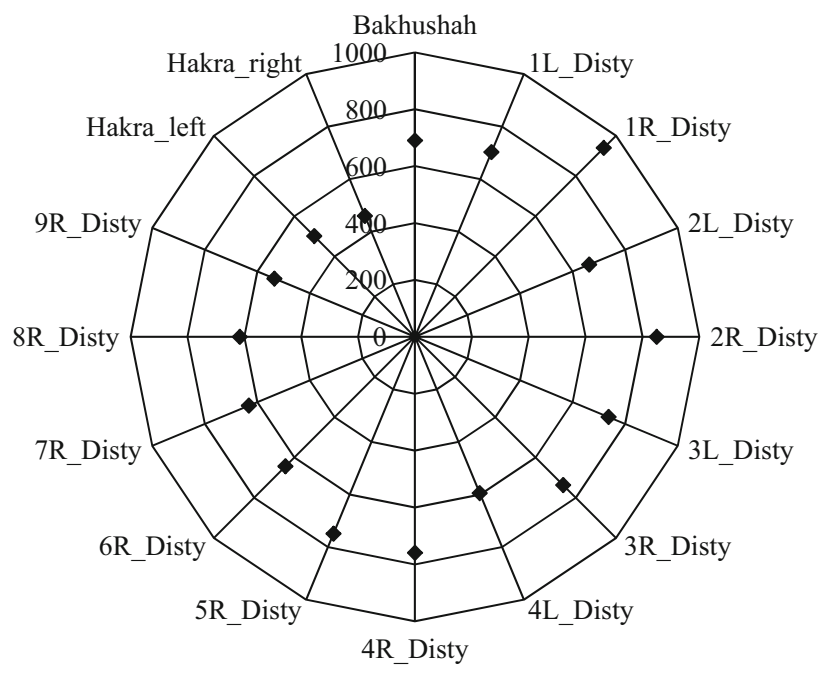

Actual evapotranspiration (mm)

(78 $\mathrm{mm})$ and August $(78 \mathrm{~mm})$ which is peak irrigation season with highest crop water demands. The minimum $\mathrm{ET}_{\mathrm{a}}$ values are during the month of December $(31 \mathrm{~mm})$ and January $(27 \mathrm{~mm})$ due to closure of canals and lowest crop water requirements (Fig. 5).

Figure 6 is showing the spatial distribution of annual actual evapotranspiration in different distributaries of Hakra canal command area. The $\mathrm{ET}_{\mathrm{a}}$ map shows the significant variation of $\mathrm{ET}_{\mathrm{a}}$ especially at head and tail end reaches of the Hakra canal. The $\mathrm{ET}_{\mathrm{a}}$ is high at the northeast side from where the Hakra canal originates and low at the south-west side which is the tail of Hakra canal.

\section{Gross and net canal water irrigation}

The annual gross canal water irrigation ( $\left.\mathrm{ICW}_{\text {gross }}\right)$ varies significantly in different distributaries of Hakra canal. The

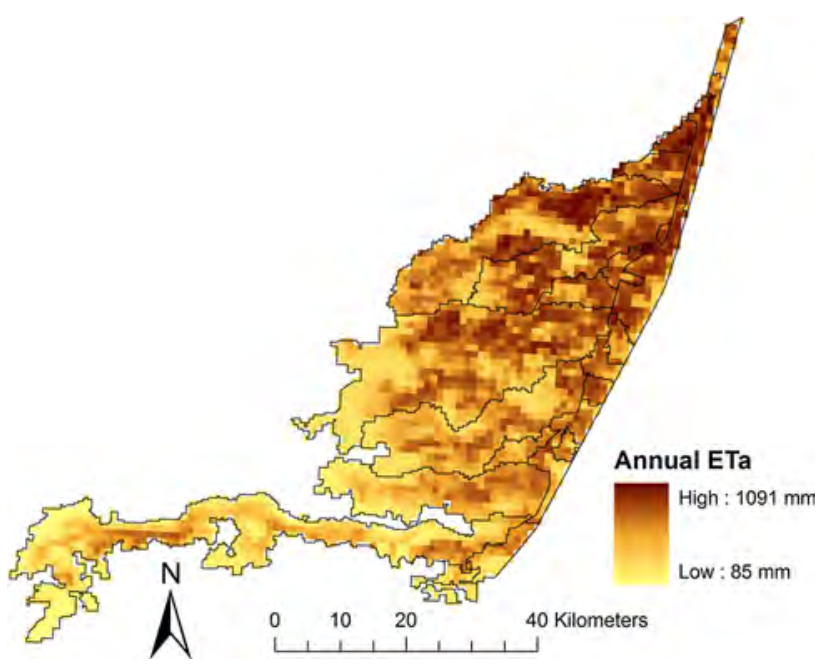

Fig. 6 Spatial distribution of actual evapotranspiration in Hakra canal command area 
maximum and the minimum $\mathrm{ICW}_{\text {gross }}$ are 833 and $434 \mathrm{~mm}$ for $3 \mathrm{~L}$ and Hakra left distributaries, respectively with an annual average of $649 \mathrm{~mm}( \pm 129)$ for Hakra canal command area (Fig. 7). There is no $\mathrm{ICW}_{\text {gross }}$ during the month of January due to closure of Hakra canal. The peak irrigation season is from June to September with highest $\mathrm{ICW}_{\text {gross }}$ during August $(67 \mathrm{~mm})$ and September $(68 \mathrm{~mm})$. These results show that the average annual $\mathrm{ICW}_{\text {gross }}$ $(649 \mathrm{~mm})$ is $49 \%$ less than the average annual crop water requirements, i.e., crop evapotranspiration $(1313 \mathrm{~mm})$.

The maximum and minimum annual average canal water irrigation $\left(\mathrm{ICW}_{\text {net }}\right)$ is 283 and $156 \mathrm{~mm}$, respectively, for $2 \mathrm{R}$ and Hakra left distributaries (Fig. 8). Average annual ICWnet which reaches the crop root-zone is only $227 \mathrm{~mm}( \pm 45)$ which is $17 \%$ of the crop evapotranspiration and $34 \%$ of the actual evapotranspiration $(676 \mathrm{~mm})$, respectively. The lowest $\mathrm{ICW}_{\text {net }}$ is in January due to closure of canal whereas maximum is from June $(21 \mathrm{~mm})$ to September $(24 \mathrm{~mm})$.

\section{Gross and net groundwater irrigation}

$\mathrm{ICW}_{\text {net }}$ and $\mathrm{ICW}_{\text {gross }}$ results show that canal water supplies in Hakra canal command areas are much lower than the crop water demand which necessitates the use of groundwater. Gross groundwater irrigation ( $\left.\mathrm{IGW}_{\text {gross }}\right)$ results show that groundwater is an integral part to meet the crop water requirements. $\mathrm{IGW}_{\text {gross }}$ is maximum $(676 \mathrm{~mm})$ for $1 \mathrm{R}$ distributary which is located at the head of the Hakra canal command area. The $\mathrm{IGW}_{\text {gross }}$ was also on the higher side for $1 \mathrm{R}$ distributary. The minimum $\mathrm{IGW}_{\text {gross }}$ was for Hakra left $(295 \mathrm{~mm})$ which is located at very tail end
Fig. 7 Gross canal water irrigation on monthly (a) and annual (b) basis in different distributaries of Hakra canal command area (a)

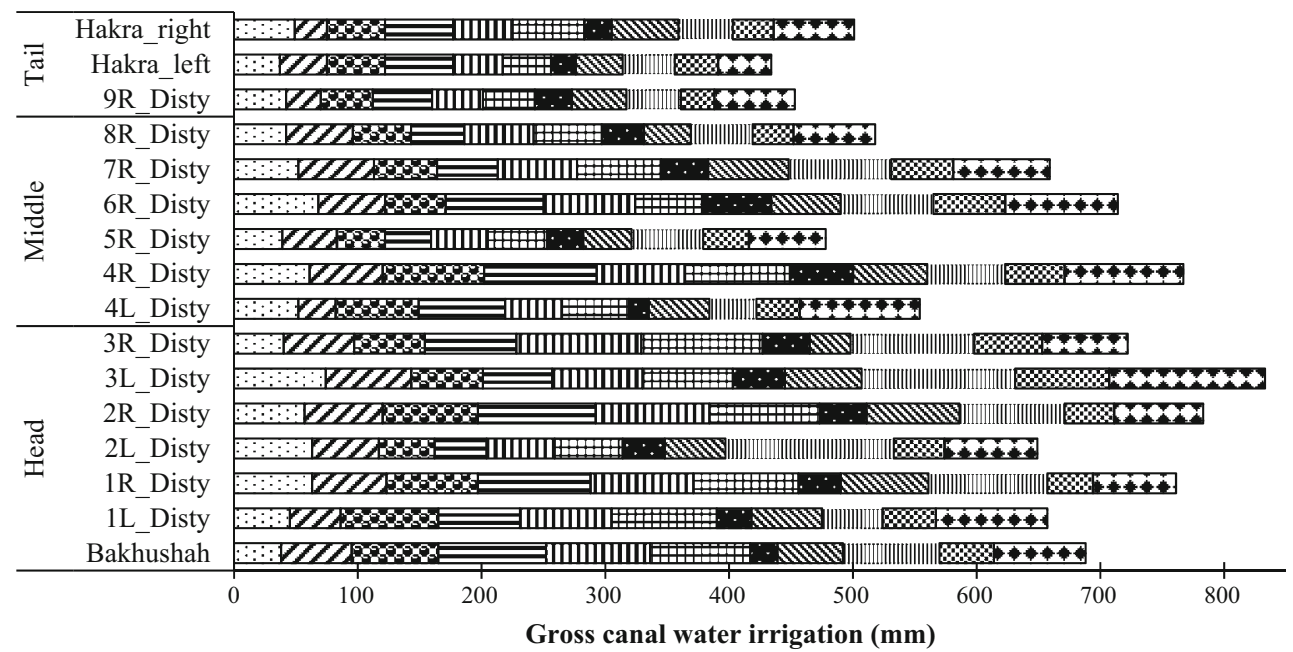

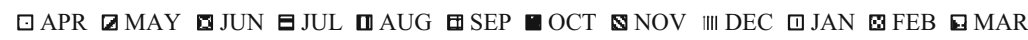

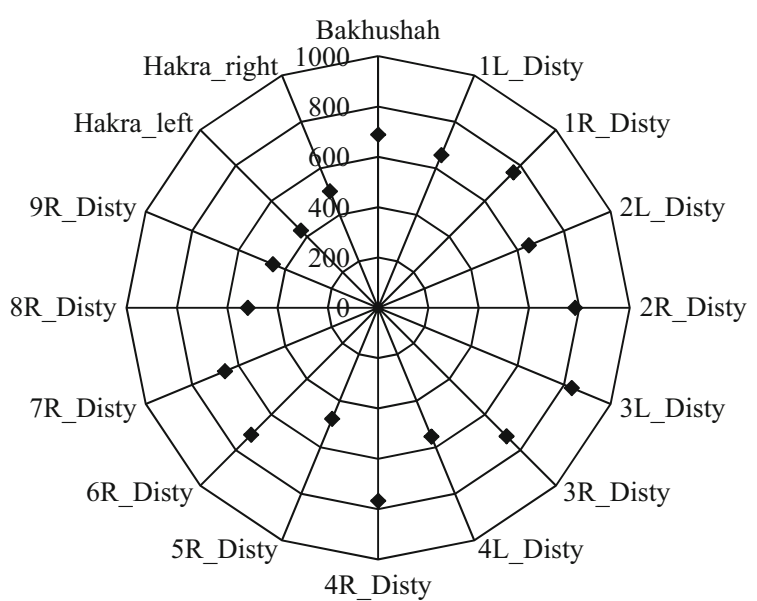

Gross canal water irrigation(mm) 
reaches of the Hakra canal (Fig. 9). This shows that head distributaries are using more canal water and groundwater as compare to tail end distributaries.

Total average annual net groundwater irrigation $\left(\mathrm{IGW}_{\text {net }}\right.$ ) is $283 \mathrm{~mm}$ which is $44 \%$ of the average annual canal water supplies (Fig. 10). However average annual groundwater contribution to actual evapotranspiration is $42 \%$. The maximum monthly average $\mathrm{IGW}_{\text {net }}$ is during the month of May whereas the minimum $\mathrm{ET}_{\mathrm{a}}$ values are during the month of February.

\section{Comparison of canal water and groundwater irrigation}

A comparison of the spatial distribution of the net irrigation supply between head, middle and tail end reaches is presented in Fig. 11. This analysis reveals that farmers located at the head end reaches receive $40 \%$ of the total net irrigation supply by Hakra canal whereas farmers located at the middle and tail end reaches receives only 34 and $26 \%$ net irrigation supplies, respectively.

A comparison of spatial distribution of actual evapotranspiration at the head, middle and tail end reaches is presented in Fig. 11. Results show that $40 \%$ of the total actual evapotranspiration is from head end reaches which reduces to 35 and $25 \%$ only for middle and tail end reaches. The difference between actual evapotranspiration at head and middle reaches is only $10 \%$. However, actual evapotranspiration at tail end reaches is $13 \%$ lower than at head end reaches.

A comparison of spatial distribution of net groundwater irrigation at head, middle and tail end reaches is presented
Fig. 8 Net canal water irrigation on monthly (a) and annual (b) basis in different distributaries of Hakra canal command area

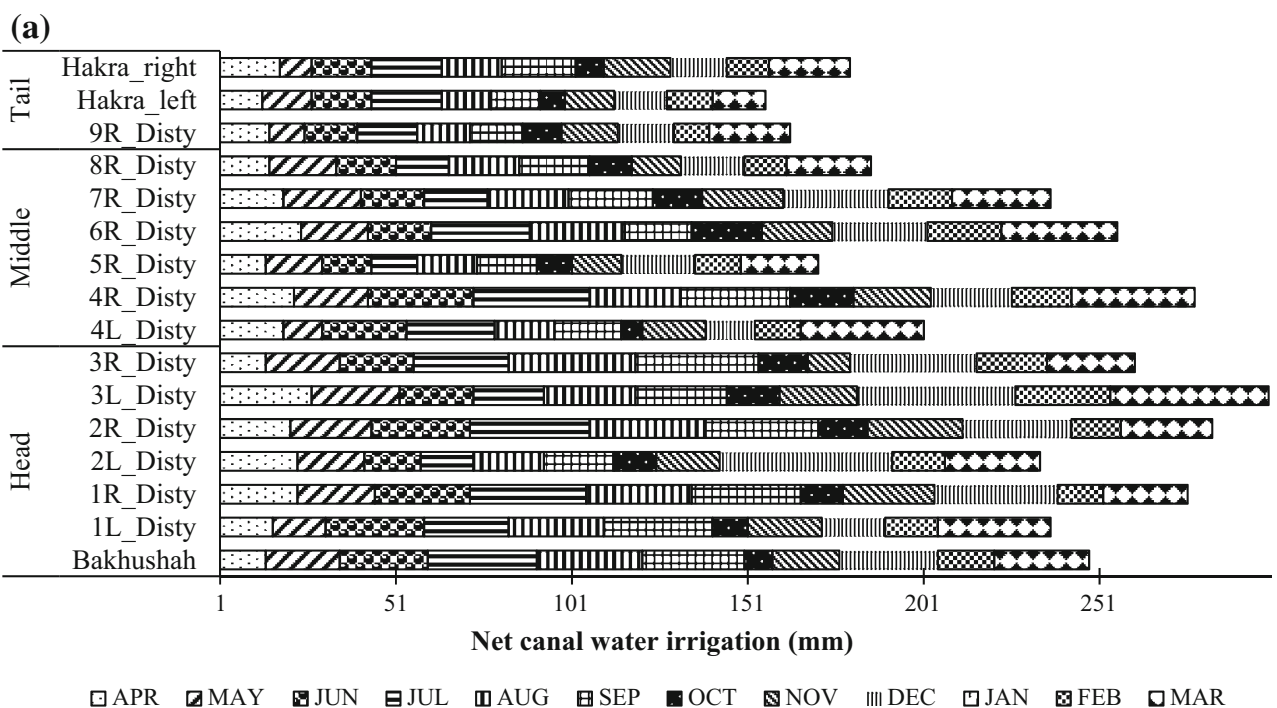

(b)

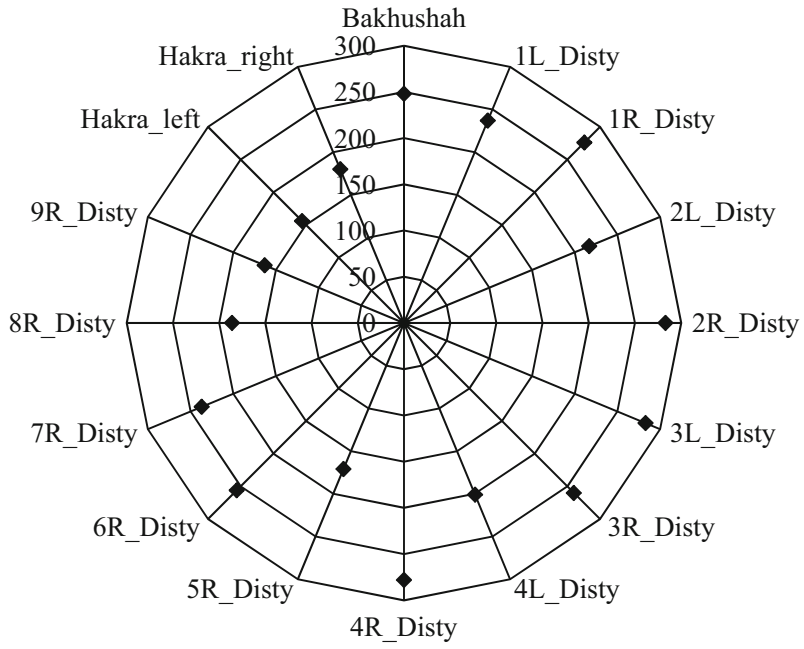

Net canal water irrigation(mm) 
in Fig. 11. The results show that farmers located at the head end reaches uses $42 \%$ groundwater whereas farmer located at the middle and tail end reaches use only 35 and $23 \%$, respectively. This indicates that farmers at the middle and tail end reaches of the Hakra canal command area uses 8 and $27 \%$ less water than farmers at the headend reaches of Hakra canal.

\section{Discussion}

Water allowances and water duties for irrigation water use in the Indus basin have been developed during colonial times. It is a well-recognized fact that current water supplies are scarce especially after the green revolution (Jurriens et al. 1996; Brewer et al. 1999). Ullah et al. (2001) reported that canal water supplies are only one third of the crop water requirements. In current study we estimated this canal water scarcity at two levels, i.e., at the head of distributary and at the root-zone. We found that only $649 \mathrm{~mm}$ water is available at the head of canal against demand of $1313 \mathrm{~mm}$ at field level. This shows that canal water supplies at the head of distributaries are only $51 \%$ of the actual crop water requirements. This means that even if irrigation network efficiency is increased to $100 \%$ (no losses during field application and during irrigation network), still there is $49 \%$ deficiency of canal water supplies. Estimates of water scarcity at root-zone depicts even worse situation. Results show that canal water supply (net irrigation) at the root zone is only $234 \mathrm{~mm}$ against demand of $1313 \mathrm{~mm}$. This means that irrigation system is providing only $18 \%$ canal water of the crop water requirements. Crop water demands depend upon agro-climatic conditions. Ullah et al. (2001) reported that crop water demand is
Fig. 9 Net groundwater irrigation on monthly (a) and annual (b) basis in different distributaries of Hakra canal command area

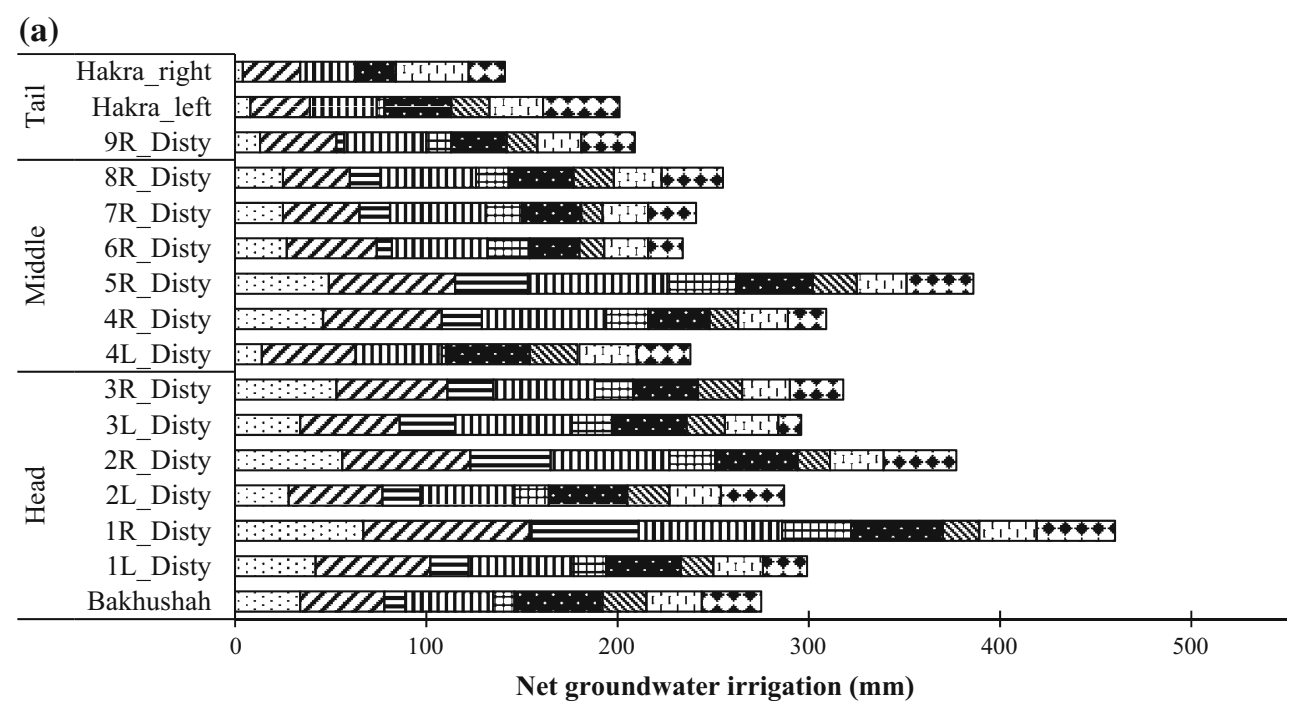

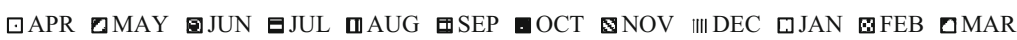

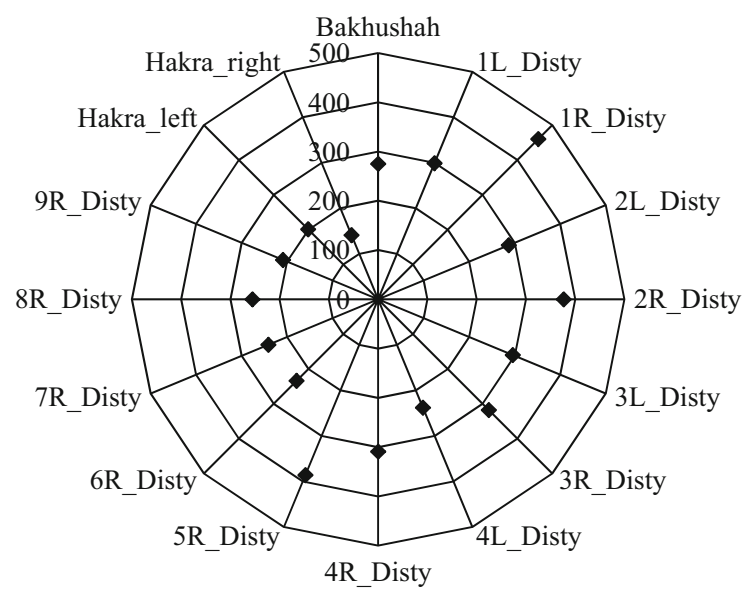

Net groundwater irrigation $(\mathrm{mm})$ 
Fig. 10 Gross groundwater irrigation on monthly (a) and annual (b) basis in different distributaries of Hakra canal command area

(a)

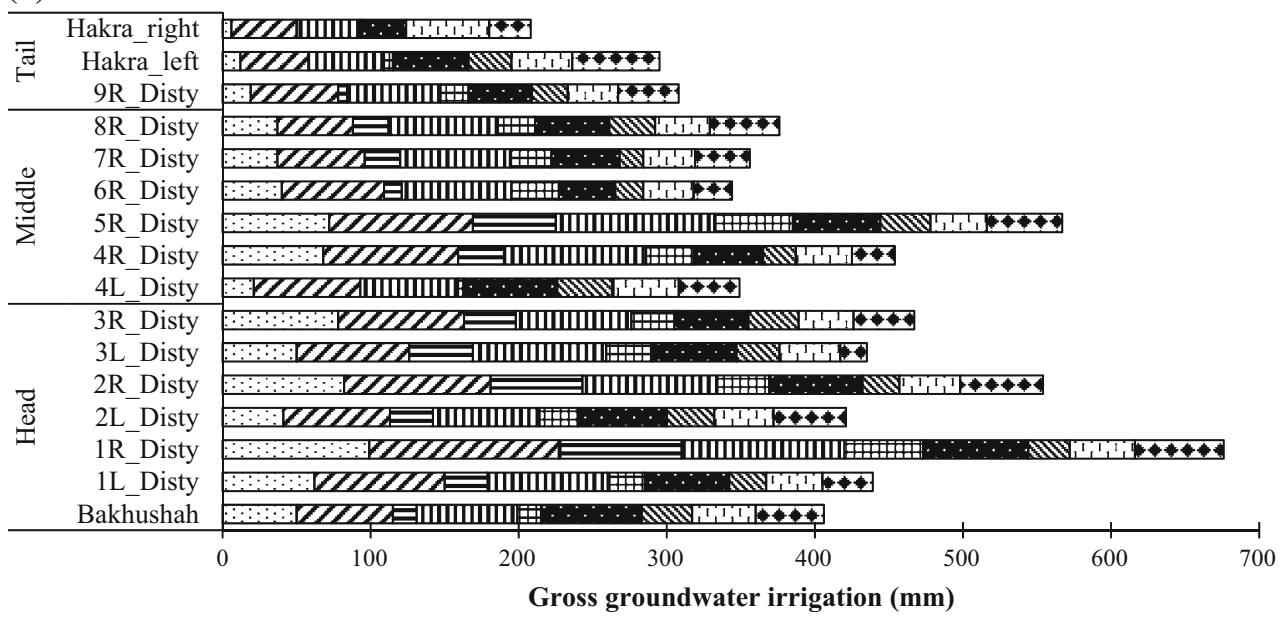

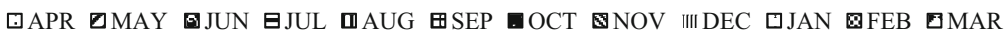

(b)

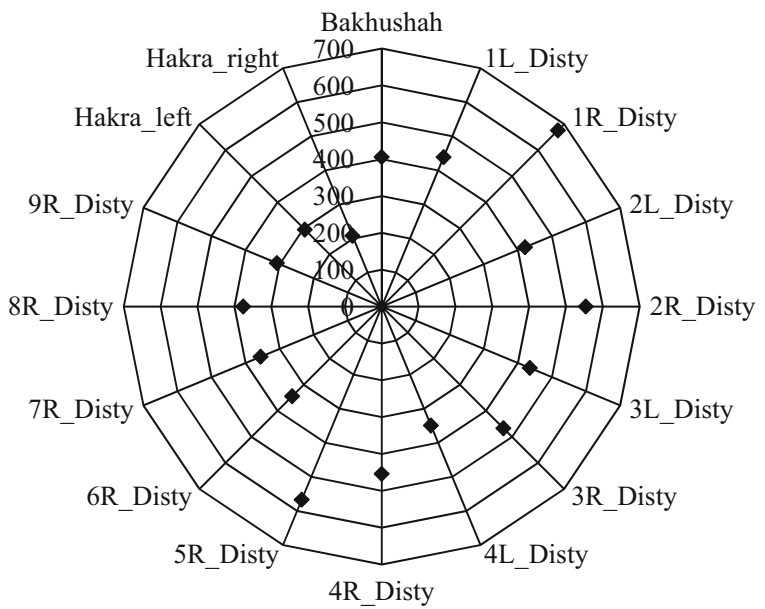

Gross groundwater irrigation $(\mathrm{mm})$

Net canal water irrigation $(\mathbf{m m})$

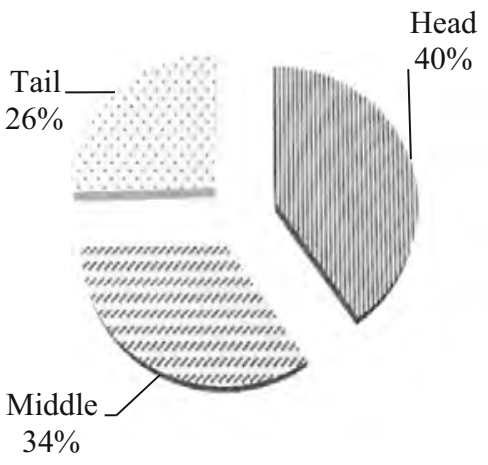

Actual evapotranspiration (mm)
Net groundwater irrigation $(\mathbf{m m})$

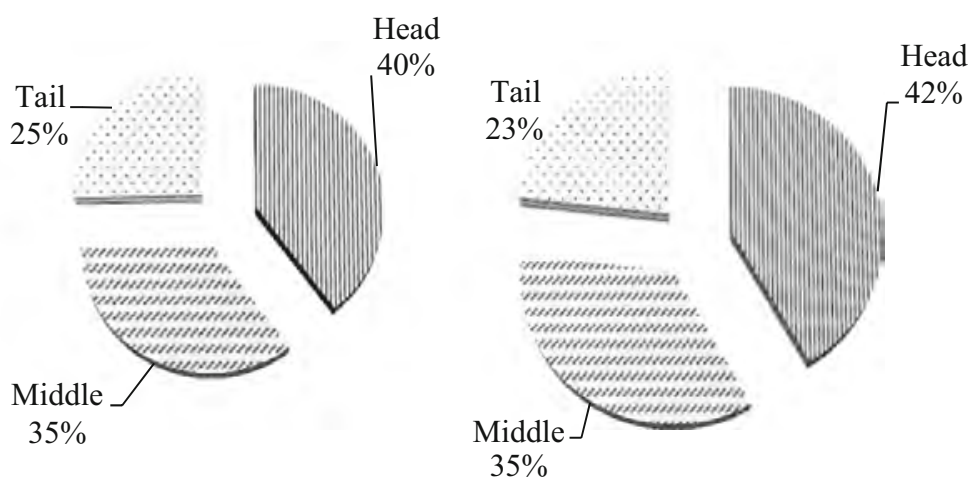

Fig. 11 Net canal water irrigation (a), actual evapotranspiration and net groundwater irrigation at head, middle, and tail end reaches of Hakra canal command area 
different for different canal command areas in Indus basin. Ullah et al. (2001) further reported that variation in demand between different agro-climatic conditions is due to change in cropping patterns and variation in reference evapotranspiration. Although Hakra canal command area is representative of the climatic conditions of the Punjab province but still comparison between water scarcities at different canal command area is suggested. Nevertheless results in case canal command area of Hakra canal shows that canal water scarcity at the head of Hakra canal and at the root zone is alarming.

Access to groundwater by tubewell irrigation has assisted poor farmers in Pakistan not only to improve their livelihoods, but also to reduce their vulnerability against surface water shortages and droughts. There are studies which describes the inequity of canal water use in the region (Alexandridis et al. 1999; Ahmad et al. 2009). However, there are very few studies which reported the volume of groundwater abstraction (e.g., Ahmad et al. 2005). Groundwater abstraction is never part of irrigation water policy in Pakistan. Like canal water which is being managed by the PID, there is no institution monitoring and regulating the groundwater abstraction. Latif and Ahmad (2008) reported that injudicious use of groundwater in Pakistan is degrading lands, lowering groundwater levels and eventually deteriorating livelihood standards in rural areas of Pakistan. Moreover, Siebert et al. (2010) and Wada et al. (2010) indicated independently that the Indus basin has one of the most overexploited groundwater systems worldwide. It is therefore of paramount importance to monitor and regulate groundwater levels for sustainable groundwater management policy. Missimer et al. (2015) reported that dams coupled with aquifer storage and recovery wells can enhance the groundwater recharge which, however, need research in the IBIS. Based upon the principle that one cannot manage what one does not measure, we quantified ground water use in Hakra canal command area. Groundwater contribution to crop water requirements was estimated at different levels. The groundwater abstraction is $47 \%$ of the actual evapotranspiration. The net ground water use is $32 \%$ of the actual evapotranspiration which is almost same to the net irrigation by canal water. The groundwater abstraction is $47 \%$ of the gross canal water supply. These results are in-line with other studies conducted in Indus basin. Shah (2007) reported that the groundwater is providing more than $50 \%$ of the total crop water requirements in the Indus basin. Shah (2007) reported that in both India and Pakistan, surface water long dominated irrigated agriculture is now overtaken by groundwater with groundwater now serving $60 \%$ or more of irrigated lands (Shah et al. 2007). Erenstein et al. (2007) did not quantify the groundwater abstraction but reported that groundwater provides the major share of total water supply at the farm gate in Punjab province of Pakistan. Results of this study although did not provide direct comparison but shows the intensity of groundwater use in Indus basin. We further scaled down our results to Farmer organizations (one farmer organization controls one distributary) which are main management unit in Indus basin. Results show that farmer abstract $40 \%$ more groundwater from head end distributaries than from tail end distributaries. As there is no literature found on the quantification of groundwater use at head, middle and tail end reaches, discussion with farmers are conducted to understand the reasons. Farmers reported two main reasons for low groundwater abstraction at tail end reaches, i.e., (1) groundwater is much deeper in the tail end reaches as compared to head end reaches. Farmers have to install centrifugal pumps in deeper pits or replacing centrifugal pumps with submersible pumps (Ambast et al. 2006). Groundwater at tail end reaches is often saline. Latif and Ahmad (2008) also reported the same that groundwater quality deteriorates along the canal reaches and is worse at the tail end reaches. Therefore, farmers use less groundwater as compared to farmers located at the head of distributaries. Artificial channels have also strong influence on the source and extent of saline water intrusion (Manda et al. 2014) which in turn can cause the degradation of the irrigation schemes.

\section{Conclusions}

Surface water resources are notably scarce in the Hakra canal command area which even combined with groundwater do not fulfill crop water requirements. Groundwater resource is vulnerable to human induced activities and therefore require proper management. Benefit of geo-informatics techniques is to capture the spatial distribution of groundwater use at high temporal resolution in a given canal command area. Groundwater quantification at head, middle and tail end reaches of Hakra canal command area provides information which can easily be interpreted in water management framework for efficient and optimal use of groundwater resource. Comparison of canal water irrigation and groundwater irrigation at different spatial and temporal scales is another proxy which can assist water managers for conjunctive use of surface and groundwater resources.

Acknowledgments This research was conducted with support from the Embassy of the Kingdom of The Netherlands, Islamabad, Pakistan through Grant \#22294, and the CGIAR Research Program on Water, Land and Ecosystems (WLE). The authors would like to acknowledge the contribution of fellow researchers, senior staff members and the reviewers whose comments and questions helped us improving this paper. The study design, analysis and interpretation of the results are exclusively those of the authors. The authors are also grateful to two reviewers for their helpful and supportive comments. 


\section{References}

Ahmad MD, Bastiaanssen WGM, Feddes RA (2005) A new technique to estimate net groundwater use across large irrigated areas by combining remote sensing and water balance approaches, Rechna Doab,Pakistan. Hydrogeol J 13:653-664

Ahmad MUD, Turral H, Nazeer A (2009) Diagnosing irrigation performance and water productivity through satellite remote sensing and secondary data in a large irrigation system of Pakistan. Agric Water Manag 96(4):551-564

Alexandridis T, Asif S, Ali S (1999) Water performance indicators using satellite imagery for the Fordwah Eastern Sadiqia (South) Irrigation and Drainage Project (No. H024895). International Water Management Institute

Ambast SK, Ashok K, Keshari Gosain AK (2006) Satellite remote sensing to support management of irrigation systems: concepts and approaches. Irrig Drain syst 5:15-39

Awan UK, Tischbein B, Conrad C, Martius C, Hafeez M (2011) Remote sensing and hydrological measurements for irrigation performance assessments in a water user association in the Lower Amu Darya River Basin. Water Resour Manag 25(10):2467-2485

Bandara KMPS (2006) Asessing irrigation performance by using remote sensing. Doctoral thesis. Wageningen University, Wageningen, The Netherlands

Bastiaanssen WGM, Menenti M, Feddes RA, Holtslag AAM (1998) A remote sensing surface energy balance algorithm for land (SEBAL), Part 1: formulation. J Hydrol 212-213:198-212

Bastiaanssen WGM, Ahmad MD, Chemin Y (2002) Satellite surveillance of water use across the Indus Basin. Water Resour Res 38(12):1273-1282

Brewer JD, Kolavalli S, Kalro AH, Naik G, Ramnarayan S, Raju KV, Sakthivadivel R (1999) Irrigation management transfer in India: policies, processes and performance. Oxford, New Delhi

Castaño S, Sanz D, Gómez-Alday JJ (2010) Methodology for quantifying groundwater abstractions for agriculture via remote sensing and GIS. Water Resour Manag 24:795-814

Chowdhury A, Jha MK, Machiwal D (2003) Application of remote sensing and GIS in groundwater studies: an overview. In: Proceedings of the international conference on water and environment (WE-2003). Ground Water Pollution, 15-18 December, 2003, M.P., India 39-50

Conrad C, Dech SW, Hafeez M, Lamers J, Martius C, Strunz G (2007) Mapping and assessing water use in a Central Asian irrigation system by utilizing MODIS remote sensing products. Irrig Drain Syst 21(3-4):197-218

Erenstein O, Malik RK, Singh S (2007) Adoption and impacts of zero tillage in the irrigated rice-wheat systems of Haryana, India. New Delhi, India: CIMMYT India and RWC

George BA, Reddy BRS, Raghuwanshi NS, Wallender WW (2002) Decision support system for estimating reference evapotranspiration. J Irrig Drain Engg Div 128(1):1-10

Hafeez M, Bouman B, Van De Giesen N, Mushtaq S, Vlek P, Khan S (2007) Water re-use and cost-benefit of pumping at different spatial levels in a rice irrigation system in UPRIIS, Philippines. J Phys Chem Earth 33:115-126

Hargreaves GH, Samani ZA (1985) Reference crop evapotranspiration from temperature. Appl Eng Agric 1:96-99

Hellegers PJGJ, Soppe R, Perry CJ, Bastiaanssen WGM (2009) Combining remote sensing and economic analysis to support policy decisions that affect water productivity. Irrig Sci 27(3):243-251
Hussain I, Hussain Z, Sial MH, Akram W, Farhan MF (2011) Water balance, supply and demand and irrigation efficiency of Indus basin. Pak Econ Soc Rev 49(1):13-38

Jha M, Arnold JG, Gassman PW, Giorgi F, Gu R (2006) Climate change sensitivity assessment on upper Mississippi river basin steamflows using SWAT. J Am Water Resour Assoc 42(4):997-1015

Jurriens M, Mollinga P, Wester P (1996) Scarcity by design: protective irrigation in India and Pakistan. International Institute for Land Reclamation and Improvement, Wageningen

Karatas BS, Akkuzu E, Unal HB, Asik S, Avci M (2009) Using satellite remote sensing to assess irrigation performance in water user associations in the Lower Gediz Basin, Turkey. Agric Water Manag 96:982-990

Latif M, Ahmad MZ (2008) Groundwater and soil salinity variations in a canal command area in Pakistan. Irrig Drain 58:456-468

Manda Alex K, Giuliano Angela S, Allen Thomas R (2014) Influence of artificial channels on the source and extent of saline water intrusion in the wind tide dominated wetlands of the southern Albemarle estuarine system (USA). Environ Earth Sci 71(10):4409-4419

Missimer T, Guo W, Maliva R, Rosas J, Jadoon K (2015) Enhancement of wadi recharge using dams coupled with aquifer storage and recovery wells. Environ Earth Sci 7723-7731. doi:10.1007/s12665-014-3410-7

Meijerink AMJ, Bannert D, Batelaan O, Lubczynski MW, Pointet T (2007) Remote sensing applications to groundwater. IHP-VI Series on Groundwater, No. 16, UNESCO, Paris, France

Muthuwatta LP, Ahma MD, Bos MG, Rientjes THM (2010) Assessment of water availability and consumption in the Karkheh River Basin-Iran-using remote sensing and geostatistics. Water Resour Manag 24:459-484

Page ML, Berjamy B, Fakir Y, Bourgin F, Jarlan L, Abourida A, Benrhanem M, Jacob G, Huber M, Sghrer F, Simonneaux V, Chehbouni G (2012) An integrated DSS for groundwater management based on remote sensing. The case of a semi-arid aquifer in Morocco. Water Resour Manag 26(11):3209-3230

Shah T (2007) The groundwater economy of South-Asia: an assessment of size, significance and socio-ecological impacts. In: Giordano M, Villholth KG (eds) The agricultural groundwater revolution: opportunities and threat to development. CABI Publications, Wallingford, pp 7-36

Shah T, Burke J, Villholth K (2007) Groundwater: a global assessment of scale and significance. In: Molden D (ed) Water for Food, Water for Life. Earthscan, London, pp 395-423

Siebert S, Burke J, Faures JM, Frenken K, Hoogeveen J, Döll P, Portmann FT (2010) Groundwater use for irrigation - a global inventory. Hydrol Earth Syst Sci 14:1863-1880. doi:10.5194/ hess-14-1863-201

Todd DK, Mays LW (2005) Groundwater hydrology. Wiley, Hoboken, p 2005

Ullah MK, Habib Z, Muhammad S (2001) Spatial distribution of reference and potential evapotranspiration across the Indus Basin Irrigation Systems. International Water Management Institute, Lahore (IWMI working paper 24)

Vieceli $\mathrm{N}$ et al (2014) Morphometric evaluation of watersheds in Caxias do Sul City, Brazil, using SRTM (DEM) data and GIS. Environ Earth Sci 73(9):5677-5685

Wada Y, van Beek LPH, van Kempen CM, Reckman, Vasak S, Bierkens MFP (2010) Global depletion of groundwater resources. Geophys Res Lett 37:L20402. doi:10.1029/ 2010GL044571 